\title{
Multidrug resistance in Klebsiella pneumoniae: a novel gene, ramA, confers a multidrug resistance phenotype in Escherichia coli
}

\author{
Anthony M. George, ${ }^{1}$ Ruth M. Hall ${ }^{2}$ and H. W. Stokes ${ }^{3}$ \\ Author for correspondence: H. W. Stokes. Tel: +612850 8164. Fax: +6128508245. \\ e-mail: hstokes@ ma.bio.mq.edu.au
}

\footnotetext{
1 Department of Biochemistry and Physiology, University of Technology Sydney, PO Box 123, Broadway NSW 2007, Australia

2 CSIRO Division of Biomolecular Engineering, Laboratory for Molecular Biology, PO Box 184, North Ryde NSW 2113, Australia

3 School of Biological Sciences, Macquarie University, Sydney NSW 2109, Australia
}

\begin{abstract}
Spontaneous multidrug-resistant (Mdr) mutants of Klebsiella pneumoniae strain ECL8 arose at a frequency of $2.2 \times 10^{-8}$ and showed increased resistance to a range of unrelated antibiotics, including chloramphenicol, tetracycline, nalidixic acid, ampicillin, norfloxacin, trimethoprim and puromycin. A chromosomal fragment from one such mutant was cloned, and found to confer an Mdr phenotype on Escherichia coli K12 cells that was essentially identical to that of the $K$. pneumoniae mutant. Almost complete loss of the OmpF porin in the $E$. coli transformant, and of the corresponding porin in the $K$. pneumoniae mutant, was observed. The presence of the Mdr mutation in $K$. pneumoniae or the cloned $K$. pneumoniae ramA (resistance antibiotic multiple) locus in $E$. coli also resulted in active efflux of tetracycline, and increased active efflux of chloramphenicol. After transformation of a ramA plasmid into E. coli, expression of chloramphenicol resistance occurred later than expression of resistance to tetracycline, puromycin, trimethoprim and nalidixic acid. The ramA gene was localized and sequenced. It encodes a putative positive transcriptional activator that is weakly related to the $E$. coli MarA and SoxS proteins. A ramA gene was also found to be present in an Enterobacter cloacae fragment that has previously been shown to confer an Mdr phenotype, and it appears that ramA, rather than the romA gene identified in that study, is responsible for multidrug resistance. The ramA gene from the wild-type $K$. pneumoniae was identical to that of the mutant strain and also conferred an Mdr phenotype on E. coli, indicating that the mutation responsible for Mdr in K. pneumoniae had not been cloned.
\end{abstract}

Keywords: multidrug resistance, RamA, Klebsiella pneumoniae, antibiotic efflux

\section{INTRODUCTION}

The antibiotic-resistant mutants that arise spontaneously in bacterial populations are generally resistant to only one antibiotic. However, in Klebsiella pneumoniae an unusual class of multidrug-resistant mutants (Mdr) which exhibit simultaneous resistance to the structurally unrelated antibiotics nalidixic acid, trimethoprim and chloramphenicol have been isolated by selection with any one of these antibiotics (Williams Smith, 1976; Gutmann et al., 1985). Similar mutants have also been isolated from

Abbreviations: CCCP, carbonyl cyanide $m$-chlorophenylhydrazone; DNP, 2,4-dinitrophenol; OMP, outer-membrane protein.

The GenBank accession number for the sequence reported in this paper is U19581.
Serratia marcescens and Enterobacter species (Dang et al., 1988; Gutmann et al., 1985; Traub \& Kleber, 1977; Cohen et al., 1993b). Mutants of this class have also been isolated by selection for resistance to $\beta$-lactam antibiotics or to fluoroquinolones such as norfloxacin and ciprofloxacin (Sanders et al., 1984; Then \& Angehrn, 1986). Multidrug-resistant mutants were found to have substantially reduced levels of at least one major outermembrane protein (OMP) (Dang et al., 1988; Gutmann et al., 1985; Sanders et al., 1984), and to exhibit reduced uptake of chloramphenicol (Gutmann et al., 1985).

One of the best-studied examples of multidrug resistance is in Escherichia coli. Single-step Mar mutants of E. coli selected on the basis of increased resistance to low levels of tetracycline or chloramphenicol also exhibit increased 
resistance to nalidixic acid, rifampicin, penicillins and cephalosporins (George \& Levy, 1983a). In Mar mutants, resistance to higher levels of these antibiotics can be obtained by subsequent rounds of growth in the presence of incrementally increased amounts of antibiotic (George \& Levy, 1983a). Mar mutants have also been shown to be resistant to fluoroquinolones (Cohen et al., 1989), and mutants isolated on the basis of resistance to norfloxacin or ciprofloxacin (NorB, NfxC, CfxB) which exhibit cross resistance to unrelated antibiotics, have also been isolated (Hirai et al., 1986; Hooper et al., 1989; Hooper et al., 1992). All of these mutants exhibit substantially reduced levels of the outer-membrane porin $\mathrm{OmpF}$ (Cohen et al., 1988b, 1989; Hooper et al., 1989). However, loss of $\mathrm{OmpF}$ alone cannot account for the increased levels of resistance in Mar mutants, as Mar mutants can be isolated from OmpF-deficient strains (Cohen et al., 1989). An energy-dependent efflux of tetracycline from intact Mar cells has been reported (George \& Levy, 1983a). The energy-dependent accumulation of norfloxacin is also reduced in a Mat mutant; however, this reduction could not be ascribed to changes in the level of the endogenous norfloxacin efflux system (Cohen et al., 1989). Thus, the mechanism of multidrug resistance is not well understood.

In E. coli, a $\operatorname{Tn} 5$ insertion at a locus designated $\operatorname{mar} A$ has been shown to abolish the multidrug resistance phenotype of Mar mutants, and Mar mutants cannot be isolated from E. coli strains carrying this insertion (George \& Levy, $1983 \mathrm{~b}$ ), implying a critical role for $\operatorname{mar} A$ in eliciting the $M d r$ phenotype. The mar $A$ region of $E$. coli has been cloned (Hachler et al., 1991) and a $7 \cdot 8 \mathrm{~kb}$ DNA fragment was required to restore the ability to form Mar mutants to an E. coli strain with a $39 \mathrm{~kb}$ deletion which includes the $\operatorname{mar} A$ gene. Recently, the sequence of this $7.8 \mathrm{~kb}$ region has been reported, and an operon consisting of three ORFs, $\operatorname{marR}, \operatorname{mar} A$ and $\operatorname{mar} B$, was identified (Cohen et al., 1993a). The alterations in several Mar mutants were localized to the $\operatorname{mar} \mathrm{R}$ gene and the marO region, which is believed to be recognized by MarR acting as a negative regulator of $\operatorname{mar} R A B$ transcription. This notion is consistent with the fact that the level of transcripts of the $\operatorname{mar} A$ region is increased in Mar mutants (Hachler $e t$ al., 1991). It has also been proposed that MarA is a positive effector of the transcription of other dispersed loci (Cohen et al., 1993a; Gambino et al., 1993), as MarA is related to several known transcriptional activators. The many pleiotropic phenotypes of Mar mutants would then be caused by changes in the level of expression of perhaps many different genes.

Here we report the further characterization of spontaneous Mdr mutants of $K$. pneumoniae. A number of the phenotypes of these mutants, including resistance to a range of structurally unrelated antibiotics, the levels of the major OMPs and energy-dependent uptake of tetracycline and of chloramphenicol by wild-type cells and $\mathrm{Mdr}$ mutant cells, were examined. A $K$. pneumoniae locus (designated $\operatorname{ram} A$ ) that confers an $M d r$ phenotype in $E$. coli was cloned from the Mdr mutant and the effects of the $\operatorname{ram} A$ fragment on the outer-membrane composition of, and uptake of antibiotics by, E. coli were examined. The gene, $\operatorname{ram} A$, responsible for the $\mathrm{Mdr}$ phenotype was localized and sequenced, and the $\operatorname{ram} A$ gene from wildtype $K$. pneumoniae was also recovered and sequenced.

\section{METHODS}

Strains and plasmids. The cell lineage and history of the $K$. pneumoniae strain ECL8 is described in Forage \& Lin (1982). Briefly, ECL8 is a met $\mathrm{Sm}^{\mathbf{r}}$ derivative of strain NCIB418 which probably dates from the original collection of Pfeiffer (1889). ECL8 is also resistant to trimethoprim (this study). ECL8 Mdr1 is a spontaneous Mdr mutant of ECL8 (this study). E. coli strains used were JM101 (supE thi-1 (lac-pro $A B) F^{\prime}\left[\operatorname{traD} 36\right.$ pro $A B^{+}$

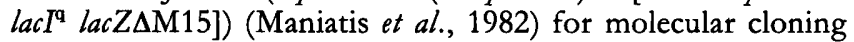
experiments and AG100 argE3 thi-1 rpsL xyl mtl supE44 $\Delta($ gal-uvrB) (George \& Levy, 1983b) for hybridization. The multicopy plasmid vector pUC18 (Yanisch-Perron et al., 1985) was used as the cloning vector. pASS20 contains a $1.26 \mathrm{~kb}$ fragment that completely includes the $\operatorname{mar} \mathrm{R} A B$ operon from $E$. coli (A. Seoane \& S. Levy, unpublished). pMAQ43 contains a $3.0 \mathrm{~kb}$ fragment of $K$. pneumoniae chromosomal DNA from ECL8 Mdr1 cloned into pUC18, and was constructed as follows. Chromosomal DNA, extracted from ECL8 Mdr1 by the method of Silhavy et al. (1984), was digested to completion with $\mathrm{BamHI}$ and ligated to pUC18 cut with the same enzyme. The ligation mixture was transformed into E. coli JM101, and recombinants were selected by plating cells onto $\mathrm{L}$ agar containing $20 \mu \mathrm{g}$ ampicillin $\mathrm{ml}^{-1}$ and $10 \mu \mathrm{g}$ chloramphenicol ml $\mathrm{m}^{-1}$. Two transformants were obtained, and BamHI digestion of plasmid DNA from these clones revealed that both included two inserted $B a m \mathrm{HI}$ fragments of 1.0 and $3.0 \mathrm{~kb}$. Plasmids from chloramphenicol-resistant transformants recovered after digestion of one of these recombinants with $\mathrm{BamHI}$, followed by re-ligation, contained only the $3.0 \mathrm{~kb} B a m \mathrm{HI}$ fragment. One of these recombinant plasmids was designated $\mathrm{pMAQ} 43$. Subclones of the $3.0 \mathrm{~kb}$ fragment were obtained by digestion of pMAQ43 DNA with appropriate restriction enzymes $(K p n \mathrm{I}$ for PMAQ98, and $X b o I$ and $S a l I$ for pMAQ154), re-ligation and transformation with selection for ampicillin resistance. Transformants were screened for resistance to chloramphenicol and plasmids were mapped to confirm the presence of the expected fragments. pAMG8 contains a fragment from $K$. pneumoniae ECL8 genomic DNA cloned by PCR amplification. Primers were 5'-AAGGATCCATGGCCGATCAGGGCGTT-3' and 5'-GCGGATCCAGACGCTGTGGGCCAGTT-3', corresponding to bases 1927-1944 and 74-95, respectively, in Fig. 5, with additional bases to create a Bam $\mathrm{HI}$ site at each end. Amplification was performed according to the proceedure of Innis \& Gelfand (1990), using an automated Fast Thermal Sequencer FTS320 (Corbett Research,) and Tli polymerase (Promega). The amplified fragment was digested with $\mathrm{BamHI}$ and cloned into pUC18. A clone with the insert in the same orientation as the fragment in PMAQ43 was designated pAMG8.

Media. L broth contained $\left(1^{-1}\right): 10 \mathrm{~g}$ tryptone, $5 \mathrm{~g}$ yeast extract and $10 \mathrm{~g} \mathrm{NaCl}$. Minimal M9 medium ( $\mathrm{pH} 7 \cdot 4$ ) contained: $6 \mathrm{~g}$ $\mathrm{Na}_{2} \mathrm{HPO}_{4} \mathrm{l}^{-1}, 3 \mathrm{~g} \mathrm{KH}_{2} \mathrm{PO}_{4} \mathrm{l}^{-1}, 0.5 \mathrm{~g} \mathrm{NaCl} \mathrm{l}^{-1}, 1 \mathrm{~g} \mathrm{NH}_{4} \mathrm{Cl} \mathrm{l}^{-1}$, $2 \mathrm{mM} \mathrm{MgSO}_{4}, 0.1 \mathrm{mM} \mathrm{CaCl}, 0.2 \%$ glucose, $0.01 \%$ thiamine and $0.1 \%$ Casamino acids (Oxoid). Media were solidified by the addition of $1.5 \%$ (w/v) BactoAgar (Difco). Antibiotics (Sigma) were added at the concentrations required in individual experiments.

Estimation of mutation frequency. About 1000 cells from an overnight L broth culture of ECL8 were used to inoculate each of nine independent $10 \mathrm{ml} \mathrm{L}$ broth cultures, which were grown overnight at $37^{\circ} \mathrm{C}$ with aeration. Appropriate dilutions of each culture were plated on $\mathrm{L}$ agar to determine viable count and 
triplicate $0.1 \mathrm{ml}$ aliquots were plated on $\mathrm{L}$ agar supplemented with $\left(10 \mu \mathrm{g}\right.$ chloramphenicol ml $\left.{ }^{-1}\right)$ to determine the number of $\mathrm{Mdr}$ cells in the culture. Mutation frequency was calculated using the method of the median (Lea \& Coulsen, 1949).

Antibiotic susceptibility testing. Levels of antibiotic resistance were determined by a gradient plate method (Szybalski \& Bryson, 1952) in square Petri dishes containing two $L$ agar wedges, the top one of which was supplemented with antibiotic. Logarithmic phase cultures were adjusted to $A_{530} 0 \cdot 2$, and samples were streaked back and forth along the antibiotic gradient of the plate with cotton-tipped applicator sticks. The level of resistance for each antibiotic was estimated by measuring the limit of confluent growth after incubation for $24 \mathrm{~h}$ at $37^{\circ} \mathrm{C}$, and assuming a linear gradient. After initial estimations, accurate results were obtained by testing each strain on linear gradients with a maximum concentration not more than threefold higher than the final reading. Each estimation was duplicated and recorded if the difference between the two readings was less than $10 \%$.

DNA methods. Restriction endonucleases and T4 DNA ligase were obtained from Promega, and were used according to the manufacturer's specifications. Agarose gel electrophoresis in TAE buffer was performed as described by Maniatis et al. (1982). Plasmid DNA was isolated from overnight L broth cultures by alkaline lysis (Birnboim \& Doly, 1979) and, where required, purified by caesium chloride/ethidium bromide density gradient equilibrium centrifugation (Maniatis et al., 1982). Preparation of competent cells and plasmid transformation were as described by Maniatis et al. (1982).

For sequencing, DNA fragments were cloned into M13mp18 and 19 (Yanisch-Perron et al., 1985). Sequencing was performed using a Sequenase $2.0 \mathrm{kit}$ (USB) with ITP reaction mixtures. The specific primers were 16-mers synthesised with a Pharmacia Gene Assembler Mark II. The sequence was compiled using the computer program RODENT (Pharmacia) and analysed using CLUSTALV (Higgins et al., 1992) and the GCG package (Devereux et al., 1984).

Time of expression. To test for any lag in expression of various antibiotic resistance phenotypes after transformation of pMAQ43 into E. coli, competent cells of JM101 were prepared and transformed with pMAQ43. The transformation mixture was diluted tenfold into $\mathrm{L}$ broth and aerated at $37^{\circ} \mathrm{C}$. At appropriate time intervals, samples were removed, diluted, and plated onto antibiotic-containing $\mathrm{L}$ agar. The selective plates contained antibiotics at the following concentrations: tetracycline $\left(5 \mu \mathrm{g} \mathrm{ml}^{-1}\right)$, chloramphenicol $\left(10 \mu \mathrm{g} \mathrm{ml}^{-1}\right)$, ampicillin $\left(25 \mu \mathrm{g} \mathrm{m}^{-1}\right)$, trimethoprim $\left(50 \mu \mathrm{g} \mathrm{ml}^{-1}\right)$, nalidixic acid $\left(5 \mu \mathrm{g} \mathrm{ml}^{-1}\right)$ or puromycin $\left(100 \mu \mathrm{g} \mathrm{ml}^{-1}\right)$.

Preparation and analysis of OMPs. Bacteria were grown in supplemented M9 medium containing $0.5 \%$ glucose, and were harvested at late exponential phase. OMPs were prepared according to the method of Inokuchi et al. (1985). The OMPs were solubilized and separated by the method of Laemmli (1970), using an $8 \%(\mathrm{w} / \mathrm{v})$ polyacrylamide gel containing $0.1 \%$ SDS and a discontinuous stacking gel of $3 \%$ polyacrylamide. Electrophoresis was carried out in Tris/glycine buffer at a constant current of $10 \mathrm{~mA}$ in the stacking gel and $20 \mathrm{~mA}$ in the separating gel. Gels were stained with $0 \cdot 1 \%$ Coomassie Brilliant Blue (Pharmacia). The order of the E. coli major porins, OmpF, OmpC and OmpA, in the gels was assigned by comparison with OmpF-deficient, sucrose-grown cells (Inokuchi $e$ t al., 1985), and with assignments reported previously (Pugsley \& Schnaitman, 1978). The molecular masses of protein bands were estimated from size standards (Bio-Rad) stained with Coomassie Brilliant Blue.
Antibiotic transport assays. Transport assays were performed essentially as described previously by George \& Levy (1983a) and McMurry et al. (1980). Cells were grown in L broth or supplemented $\mathrm{M} 9$ medium to $\mathrm{OD}_{530} 0 \cdot 6-0.8$. Cells were collected at $3000 \mathrm{~g}$ for $10 \mathrm{~min}$ at room temperature and were then washed in one culture volume of assay buffer, containing $50 \mathrm{mM} \mathrm{K \textrm {KO } _ { 4 } \text { and } 1 \mathrm { mM } \mathrm { MgSO }}$, $\mathrm{pH} 6.6$. The pellets were resuspended in assay buffer to $\mathrm{OD}_{530} 4 \cdot 0$. These cell suspensions were kept at $37^{\circ} \mathrm{C}$ for not more than $30 \mathrm{~min}$ before being used in uptake assays at the same temperature. Samples of suspended cells were energized with D-glucose or DL-lactate at $20 \mathrm{mM}$, and de-energized by adding carbonyl cyanide $m$-chlorophenylhydrazone (CCCP; ICN) to $50 \mu \mathrm{M}$ or 2,4-dinitrophenol (DNP; Sigma) to $2 \mathrm{mM}$. Assays were commenced by the addition of $\left[7-{ }^{3} \mathrm{H}\right]$ tetracycline $\left(0.6 \mathrm{Ci} \mathrm{mmol}^{-1} ; \quad 22 \cdot 2 \mathrm{GBq} \mathrm{mmol}^{-1}\right.$; DuPont), or D-threo-[dichloroacetyl-1 ${ }^{14} \mathrm{C}$ ]chloramphenicol ( $55 \mathrm{mCi} \mathrm{mmol}^{-1} ; 2035 \mathrm{MBq} \mathrm{mmol}^{-1}$; Amersham Australia) to $5 \mu \mathrm{M}$. Samples $(50 \mu \mathrm{l})$ were removed at intervals, diluted 100 fold in $100 \mathrm{mM} \mathrm{KPO}_{4}^{-}, 100 \mathrm{mM} \mathrm{LiCl}, \mathrm{pH} \mathrm{6.6}$, filtered through $0.45 \mu \mathrm{m}$ pore-size GN-6 Metricel membrane filters (Gelman Sciences), and washed with $5 \mathrm{ml}$ of the same dilution buffer, using a filtration manifold and vacuum pump pressure of 18 p.s.i. $(124 \cdot 2 \mathrm{kPa})$. Filters were dried at $37^{\circ} \mathrm{C}$ and counted in a xylene-based scintillant (ACSII, Amersham Australia). Membrane protein was estimated by a modified Lowry method (Markwell et al., 1978) using BSA as a standard.

Transport in starved cells. Mid-exponential phase cultures were starved for $4 \mathrm{~h}$ in unsupplemented $\mathrm{M} 9$ medium but containing $5 \mathrm{mM}$ DNP, as described by Berger \& Heppel (1974). The assay procedure was essentially as described (McMurry et al., 1987; Park \& Levy, 1988). Briefly, starved cells were washed four times with M9 medium and suspended in assay buffer to a final $\mathrm{OD}_{530} 4 \cdot 0$. Cell suspensions were incubated at $37^{\circ} \mathrm{C}$ for $30 \mathrm{~min}$ before adding $\left[{ }^{3} \mathrm{H}\right]$-tetracycline or $\left[{ }^{14} \mathrm{C}\right]-$ chloramphenicol to $5 \mu \mathrm{M}$. After a $20 \mathrm{~min}$ equilibration period, $0.25 \%$ glucose was added as an energy source. Samples were removed and filtered and counted as described above.

Southern hybridization. Chromosomal DNA from E. coli $\mathrm{AG} 100$ and $K$. pneumoniae ECL8 Mdr1 was isolated as described by Maniatis et al. (1982). The DNA from each strain was digested overnight at $37^{\circ} \mathrm{C}$ with either BamHI or PstI, resolved by electrophoresis in an agarose gel, then transferred to Hybond $\left(\mathrm{N}^{+}\right)$nylon membrane (Amersham) using a vacuum blotting apparatus (Pharmacia-LKB). The marR $A B$ probe was the $1.24 \mathrm{~kb}$ PstI fragment from pASS20 (generously provided by S. B. Levy), and the $\operatorname{ram} A$ probe was the $3.0 \mathrm{kbp} \mathrm{BamHI}$ fragment from pMAQ43 (this study). After electrophoretic separation of the restricted plasmid DNAs in an agarose gel, the probe fragments were recovered using Gene Clean (Bio 101). Probe labelling, hybridization and chemiluminescent detection of complementary DNA on X-ray film (Hyperfilm-ECL, Amersham), were done with an ECL gene detection kit (Amersham) as recommended by the manufacturer. Hybridization conditions were as described for homologous or nearhomologous probes $\left(42^{\circ} \mathrm{C}, 0.5 \mathrm{M} \mathrm{NaCl}\right)$, using both low and high stringency washes on duplicate nylon membranes.

\section{RESULTS}

\section{Isolation and characterization of $\boldsymbol{K}$. pneumoniae $\mathrm{Mdr}$ mutants}

In previous studies with $K$. pneumoniae strain ECL8 and other strains of the same lineage, it was noted that spontaneous mutants arose that exhibited a multidrug resistance phenotype (R. G. Forage, unpublished obser- 
Table 1. Levels of resistance for wild-type and Mdr strains to a range of structurally unrelated antibiotics

\begin{tabular}{|c|c|c|c|c|}
\hline \multirow[t]{2}{*}{ Antibiotic } & \multicolumn{4}{|c|}{ Antibiotic resistance $\left(\mu \mathrm{g} \mathrm{ml}^{-1}\right) *$ for the strains: } \\
\hline & ECL8 & ECL8 Mdr1 & JM101 & JM101(pMAQ43) \\
\hline Tetracycline & $1 \cdot 6$ & $16 \cdot 5$ & $1 \cdot 5$ & 15 \\
\hline Chlortetracycline & 1.9 & 18 & $1 \cdot 8$ & 20 \\
\hline Chloramphenicol & $1 \cdot 0$ & 36 & $2 \cdot 7$ & 45 \\
\hline Nalidixic acid & $1 \cdot 2$ & 35 & $1 \cdot 2$ & $12 \cdot 5$ \\
\hline Norfloxacin & 0.05 & $1 \cdot 7$ & 0.05 & $0 \cdot 8$ \\
\hline Trimethoprim & $>1000$ & $>1000$ & 4 & 80 \\
\hline Puromycin & 7 & $>860$ & 4 & $>860$ \\
\hline Ampicillin & 5 & 64 & ND & ND \\
\hline Ceftazidime & $0 \cdot 05$ & $0 \cdot 14$ & 0.05 & 0.32 \\
\hline Cephalothin & $0 \cdot 2$ & $6 \cdot 3$ & ND & ND \\
\hline Rifampicin & $6 \cdot 3$ & $12 \cdot 5$ & $1 \cdot 3$ & $4 \cdot 5$ \\
\hline Kanamycin & $1 \cdot 6$ & $2 \cdot 3$ & 0.5 & $0 \cdot 8$ \\
\hline
\end{tabular}

ND, Not determined, as PMAQ43 confers resistance to ampicillin.

* Measured by the limit of confluent growth on antibiotic gradient plates. Resistances represent the average of two determinations which differed by less than $10 \%$.

vations). To investigate this phenomenon, cells from an overnight culture of ECL8 grown without antibiotic selection were spread onto $\mathrm{L}$ agar plates containing either $20 \mu \mathrm{g}$ chloramphenicol $\mathrm{ml}^{-1}$ or $20 \mu \mathrm{g}$ nalidixic acid $\mathrm{ml}^{-1}$. One hundred colonies from each set of selection plates were tested for cross-resistance to chloramphenicol and nalidixic acid. All 100 colonies selected on chloramphenicol plates were also resistant to nalidixic acid, but of the 100 colonies selected on nalidixic acid plates, only 84 were cross-resistant to chloramphenicol. The remaining nalidixic acid-resistant mutants were presumed mostly to have mutations in the DNA gyrase gene and were not analysed further. The mutation frequency to an $\mathrm{Mdr}$ phenotype, estimated using selection for chloramphenicol resistance was $2.2 \times 10^{-8}$. One of the resistant colonies, selected with chloramphenicol, was purified, and this strain was designated ECL8 Mdr1.

Mutants of Klebsiella selected in the presence of a single antibiotic (nalidixic acid, chloramphenicol or trimethoprim), which exhibit simultaneous resistance to all three antibiotics, have been reported previously (Williams Smith, 1976; Gutmann et al., 1985). In previous studies, the mutants were also shown to exhibit resistance to tetracycline (Williams Smith, 1976), and to ampicillin and carbenicillin (Gutmann et al., 1985). The level of resistance for ECL8 Mdr1 and its parent ECL8 was determined for a range of antibiotics using a gradient plate method (Table 1). As the parent strain used in this study is resistant to high levels of trimethoprim, it was not possible to determine if the level of resistance to this antibiotic was increased in ECL8 Mdr1. ECL8 Mdr1 exhibits significant levels of resistance to many structurally unrelated antibiotics, namely tetracycline, chlortetracycline, chloramphenicol, puromycin, ampicillin, cephalothin, ceftazidime, puromycin, rifampicin, nalidixic acid and norfloxacin. The most dramatic increase was observed with puromycin. There was no increase in the level of kanamycin resistance.

\section{Cloning of a K. pneumoniae Mdr determinant}

A $3.0 \mathrm{~kb}$ Bam HI fragment which conferred an $\mathrm{Mdr}$ phenotype in $E$. coli was isolated from genomic DNA derived from $K$. pneumoniae ECL8 Mdr1. A recombinant plasmid containing this fragment was designated pMAQ43 and the locus was designated $\operatorname{ram} A$ (resistance antibiotic multiple). The antibiotic resistance levels were determined for $E$. coli strains JM101 and JM101(pMAQ43) and are shown in Table 1. E. coli cells harbouring pMAQ43 were resistant to the same antibiotics as ECL8 Mdr1, and the levels of resistance were also similar. In $E$. coli, the $\operatorname{ram} A$ locus also confers resistance to trimethoprim (Table 1). As the pUC18 vector confers ampicillin resistance it was not possible to test this phenotype.

\section{Lag in expression of the chloramphenicol resistance phenotype}

In the course of the above work it was observed that selection of transformants containing pMAQ43 was significantly less efficient with chloramphenicol than with nalidixic acid, despite the fact that all transformants recovered were resistant to both antibiotics. The possibility that chloramphenicol resistance was expressed later than nalidixic acid resistance was therefore investigated. pMAQ43 was transformed into JM101, and the number of transformants recovered after different periods of expression was measured for ampicillin resistance (determined by the vector), and for tetracycline, puromycin, 
Table 2. Time-course of expression of resistance after transformation of JM101 with pMAQ43

\begin{tabular}{|c|c|c|c|c|c|}
\hline \multirow[t]{2}{*}{ Time (h) } & \multicolumn{5}{|c|}{ No. of transformants selected on *: } \\
\hline & $\begin{array}{l}\text { Ampicillin } \\
\left(25 \mu \mathrm{g} \mathrm{ml}^{-1}\right)\end{array}$ & $\begin{array}{c}\text { Chloramphenicol } \\
\left(10 \mu \mathrm{g} \mathrm{ml}^{-1}\right)\end{array}$ & $\begin{array}{c}\text { Tetracycline } \\
\left(5 \mu \mathrm{g} \mathrm{ml}^{-1}\right)\end{array}$ & $\begin{array}{c}\text { Puromycin } \\
\left(100 \mu \mathrm{g} \mathrm{ml}^{-1}\right)\end{array}$ & $\begin{array}{c}\text { Nalidixic acid } \\
\left(5 \mu \mathrm{g} \mathrm{ml}^{-1}\right)\end{array}$ \\
\hline 0 & 36 & 0 & 44 & 68 & 44 \\
\hline 1 & 119 & 5 & 139 & 131 & 94 \\
\hline 2 & 308 & 36 & 328 & 348 & 263 \\
\hline 3 & 415 & 166 & 436 & 447 & 480 \\
\hline 4 & 665 & 319 & 689 & 678 & 614 \\
\hline
\end{tabular}

* $100 \mu \mathrm{l}$ aliquots from the same transformation mixture were spread over two plates of each type.

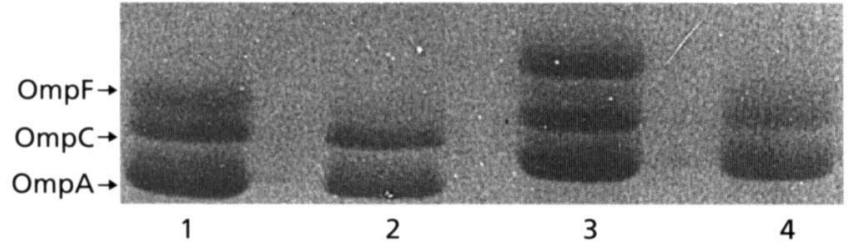

Fig. 1. SDS-PAGE profile of OMPs. Lanes: $1, E$. coli JM101; $2, E$. coli JM101(pMAQ43); 3, K. pneumoniae ECL8; 4, $K$. pneumoniae ECL8 Mdr1. The positions of the $E$. coli major porin proteins, OmpF, OmpC and OmpA, are indicated.

trimethoprim, nalidixic acid and chloramphenicol resistances (all determined by the $\operatorname{ram} A$ locus). The results are shown in Table 2 . The time-course of expression of ampicillin resistance was identical to that for resistance to tetracycline, puromycin, trimethoprim and nalidixic acid. However, the expression of chloramphenicol resistance was delayed by about $2 \mathrm{~h}$, suggesting that the expression of resistance to chloramphenicol may be different from that of resistance to the other antibiotics.

\section{Effects on the levels of OMPs}

In a previous study (Gutmann et al., 1985), a 10-fold decrease in the amount of the largest major OMP (41 kDa) was observed in a $K$. pneumoniae $\mathrm{Mdr}$ mutant. A similar effect was observed when the outer membrane compositions of ECL8 Mdr1 and ECL8 were compared (Fig. 1, lanes 3 and 4). The largest porin in ECL8 is almost completely absent from ECL8 Mdr1. In E. coli, the presence of pMAQ43 caused a substantial reduction in the level of the OmpF porin (Fig. 1, lanes 1 and 2). It is possible that the OMP that is affected in $K$. pneumoniae is equivalent to $\mathrm{OmpF}$.

\section{Efflux of tetracycline and chloramphenicol in $K$. pneumoniae and $E$. coli}

Gutmann et al. (1985) showed that chloramphenicol uptake was reduced in a $K$. pneumoniae Mdr mutant. Energy-dependent accumulation of tetracycline and chloramphenicol by susceptible and by resistant $K$. pneumoniae cells was therefore examined. Active uptake of tetracycline in susceptible cells of $K$. pneumoniae (ECL8) was observed (Fig. 2a). That uptake is energy-dependent is demonstrated by the finding that uptake was reversed in the presence of the uncouplers DNP (Fig. 2a) or CCCP (not shown), which are known to collapse the proton motive force across bacterial membranes (Rosen \& Kashket, 1978). In contrast, ECL8 Mdr1 cells exhibited an energy-dependent reduced uptake of tetracycline (Fig. 2a). When cells were first depleted of endogenous energy (see Methods), and subsequently incubated in assay buffer containing $\left[{ }^{3} \mathrm{H}\right]$ tetracycline, the accumulated tetracycline reached steady-state levels in both susceptible and resistant cells after $20 \mathrm{~min}$. On addition of exogenous glucose, active uptake of tetracycline was observed with ECL8 susceptible cells, whereas with ECL8 Mdr1 cells active efflux occurred (Fig. 2b). These results confirmed that the reduced accumulation of tetracycline seen in $\mathrm{Mdr}$ cells (Fig. 2a) is due to efflux of the drug. E. coli cells also exhibited active uptake of tetracycline (Fig. 2c, d) as has been reported previously (George \& Levy, 1983a). When pMAQ43 was present in E. coli, active efflux of tetracycline was observed (Fig. 2c, d).

With chloramphenicol, a DNP-sensitive energy-dependent reduced accumulation of drug was observed in susceptible cells of both $K$. pneumoniae and E. coli (Fig. 3a, c), and following the addition of exogenous glucose to starved cells, active efflux of chloramphenicol occurred (Fig. 3b, d). An energy-dependent efflux of chloramphenicol was also observed in ECL8 Mdr1 (Fig. 3b) and in JM101(pMAQ43) (Fig. 3d), but the extent of efflux was greater than that of susceptible cells. These data indicate that an endogenous efflux system for chloramphenicol is present in susceptible $K$. pneumoniae and E. coli, and that a stronger efflux of the drug occurs in resistant cells. This finding is in contrast to an earlier report of energydependent increased uptake of chloramphenicol in susceptible E. coli cells (Abdel-Sayed, 1987), and the reason for this difference is not clear. However, chloramphenicol efflux in susceptible E. coli cells has recently been reported (McMurry et al., 1994).

The transport studies shown in Figs 2 and 3 were also repeated using $L$ broth as medium for both the growth 

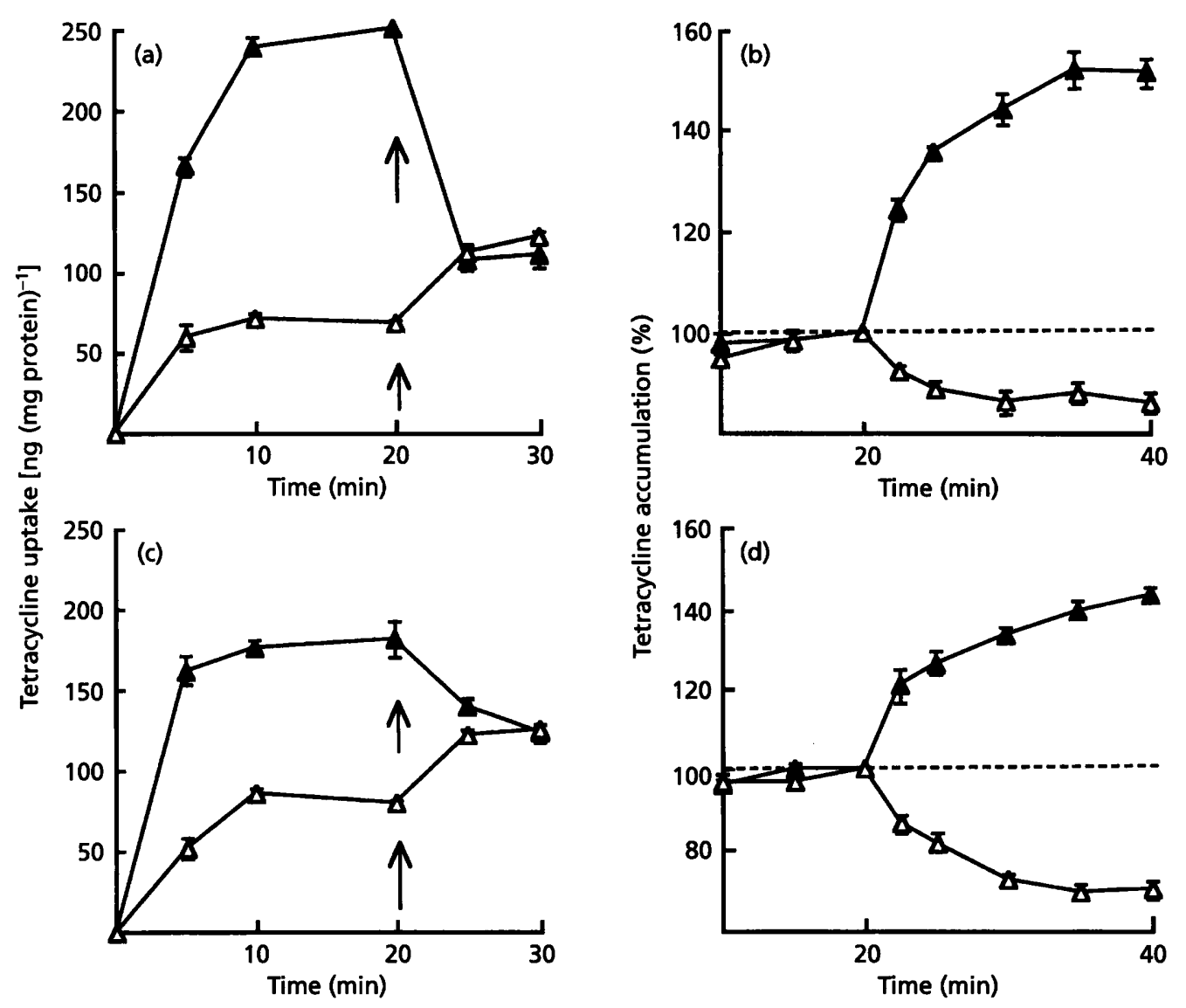

Fig. 2. Accumulation and efflux of tetracycline by susceptible and resistant $K$. pneumoniae and $E$. coli cells. (a) and (b) $K$. pneumoniae strains ECL8 $(\Delta)$ and ECL8 Mdr1 $(\triangle) ;(c)$ and $(d) E$. coli strains JM101 $(\Delta)$ and JM101 (pMAQ43) $(\triangle)$. (a) and (c) Uptake of tetracycline by whole cells; $2 \mathrm{mM}$ DNP was added at the times indicated by the arrows. Data are representative of four independent determinations. (b) and (d) Cells were starved for $4 \mathrm{~h}$ with $5 \mathrm{mM}$ DNP before being washed and resuspended in assay buffer to $\mathrm{OD}_{530} 4.0$. Data are representative of four independent determinations. Glucose $(0.25 \%)$ was added after a $20 \mathrm{~min}$ equilibration period with $5 \mu \mathrm{M}$ tetracycline, and cell-associated tetracycline concentrations are expressed as a percentage of steady state accumulation.

and the assay of cells. The results were essentially the same (data not shown), except that the extent of the efflux for both tetracycline and chloramphenicol in Mdr cells was greater than that seen using minimal medium for growth, and potassium phosphate buffer for the transport assays.

\section{Characterization of the ramA gene}

The $3.0 \mathrm{~kb}$ BamHI $K$. pneumoniae fragment present in pMAQ43 was mapped (Fig. 4) and the region responsible for conferring the Mdr phenotype was shown to be present in both a $1.95 \mathrm{~kb} \mathrm{KpnI-BamHI} \mathrm{fragment} \mathrm{and} \mathrm{a}$ $1.9 \mathrm{~kb} \mathrm{BamHI-XhoI} \mathrm{fragment,} \mathrm{indicating} \mathrm{that} \mathrm{the} \operatorname{ram} A$ gene is located within the $0.9 \mathrm{~kb} \mathrm{KpnI-XboI} \mathrm{fragment.}$ The complete sequence of the $1.95 \mathrm{~kb} K p n \mathrm{I}-\mathrm{Bam} \mathrm{HI}$ fragment was determined (Fig. 5) and the only ORF that is completely included between the $K p n \mathrm{I}$ and $X b o \mathrm{I}$ sites was identified as the $\operatorname{ram} A$ gene. This ORF encodes a polypeptide of 113 amino acids with a predicted molecular mass of $13490 \mathrm{kDa}$. The RamA polypeptide is related to several other proteins (Fig. 6) including the E. coli MarA and SoxS proteins. MarA (Cohen et al., 1993a; Gambino et al., 1993) and SoxS (Amabile-Cuevas \& Demple, 1991;
Wu \& Weiss, 1991) have previously been found to be related to the $\mathrm{N}$-terminal region of a family of proteins that includes known transcriptional activators such as AraC (Ramos et al., 1990). MarA, SoxS and RamA have similar lengths and a potential helix-turn-helix DNAbinding domain found near the $\mathrm{N}$-terminus of SoxS and MarA (Amabile-Cuevas \& Demple, 1991; Wu \& Weiss, 1991; Cohen et al., 1993a; Gambino et al., 1993) is also present in RamA (Fig. 6). One further member of this family is PqrA, which was recently identified in a fragment cloned from a multidrug-resistant isolate of Proteus vulgaris (Ishida et al., 1995). The similarity to known transcriptional activators, suggests that RamA may elicit the pleiotropic $\mathrm{Mdr}$ phenotype by activating the expression of dispersed loci, as is believed to be the case for the MarA protein (Cohen et al., 1993a; Gambino et al., 1993) and SoxS protein (Amabile-Cuevas \& Demple, 1991; Wu \& Weiss, 1991 ; Miller et al., 1994). However, the $\operatorname{ram} A$, soxS and $\operatorname{mar} A$ sequences are not significantly related.

By analogy with the Mar system of E. coli, where Mar mutants contain mutations located in the marR gene or the marO region (Cohen et al., 1993a), but the wild-type 

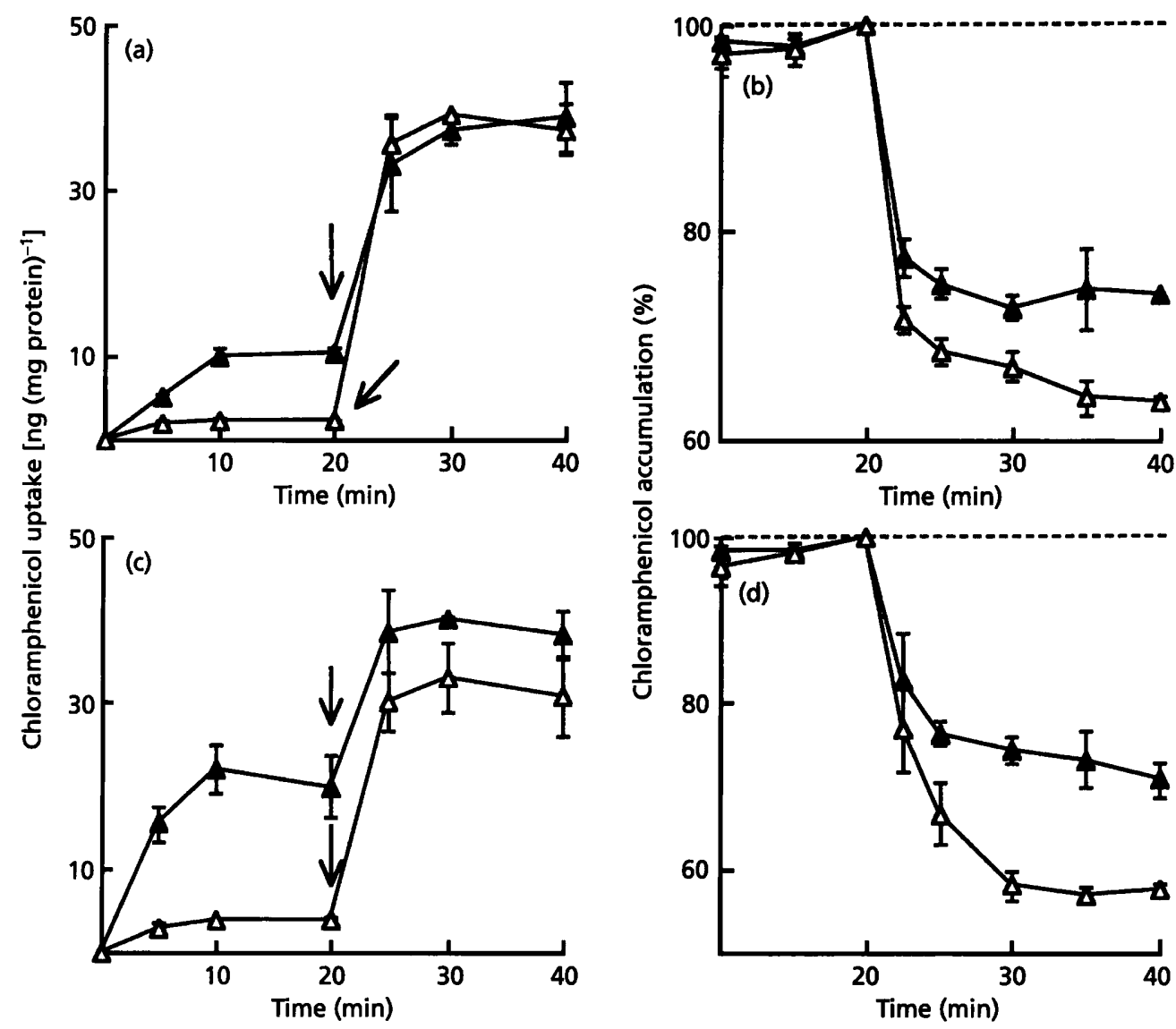

Fig. 3. Accumulation and efflux of chloramphenicol by susceptible and resistant $K$. pneumoniae and $E$. coli cells. (a) and (b) K. pneumoniae strains ECL8 $(\Delta)$ and ECL8 Mdr1 $(\triangle) ;(c)$ and (d) E. coli strains JM101 ( $\Delta$ ) and JM101(pMAQ43) ( $\triangle$ ). (a) and (c) Uptake of chloramphenicol by whole cells; $2 \mathrm{mM}$ DNP was added at the times indicated by the arrows. Data are representative of four independent determinations. (b) and (d) Cells were starved for $4 \mathrm{~h}$ with $5 \mathrm{mM}$ DNP before being washed and resuspended in assay buffer to $O_{530}$ 4.0. Data are representative of four independent determinations. Glucose $(0.25 \%$, w/v) was added after a 20 min equilibration period with $5 \mu \mathrm{M}$ chloramphenicol, and cell-associated chloramphenicol concentrations are expressed as a percentage of steady-state accumulation.

$\operatorname{mar} A$ gene cloned in a multicopy plasmid confers a Mar phenotype (Gambino et al., 1993), it seemed possible that the cloned $\operatorname{ram} A$ gene $\operatorname{did}$ not contain the mutation responsible for the Mdr phenotype of the mutant ECL8 Mdr1 from which it was cloned. To examine this possibility, the bulk of the $K$. pneumoniae $1.95 \mathrm{~kb}$ KpnI-BamHI fragment was isolated from ECL8 by PCR amplification and cloned into pUC18. In $E$. coli, the resulting plasmid pAMG8 conferred an Mdr phenotype and MICs, determined by the gradient plate method, were $25 \mu \mathrm{g}$ chloramphenicol ml ${ }^{-1}, 8 \mu \mathrm{g}$ tetracycline $\mathrm{ml}^{-1} ; 60 \mu \mathrm{g}$ trimethoprim $\mathrm{ml}^{-1}$. The sequence of the $\operatorname{ram} A$ region from ECL 8 was determined and is identical to that shown in Fig. 5 (bases 400-900), confirming that the mutation in ECL8 Mdr1 had not been cloned.

\section{Relationship of the Klebsiella ramA and Enterobacter romA genes}

The cloning of a $2.2 \mathrm{~kb}$ EcoRI Enterobacter cloacae fragment, which confers on $E$. coli a multiple antibiotic resistance phenotype similar to that conferred by $\operatorname{ram} A$, has been reported (Komatsu et al., 1990). The presence of this fragment also caused a reduction in the level of a major OMP in Enterobacter, and of OmpF in E. coli, as well as the production of at least two new OMPs in E. coli (Komatsu et al., 1990). The fragment has been sequenced and the $\operatorname{rom} A$ gene, which encodes a 368 amino acid putative OMP, was identified as the gene responsible for the $\mathrm{Mdr}$ phenotype (Komatsu et al., 1990). No similarity between the $\operatorname{ram} A$ sequence and the $\operatorname{rom} A$ gene was detected in searches of sequences in the DNA databases. However, as the phenotypes conferred by the $K$. pneumoniae $\operatorname{ram} A$-containing fragment and the Ent. cloacae $\operatorname{rom} A$-containing fragment are similar, we examined this question in more detail and found that the $\operatorname{rom} A$ sequence is not present in the databases.

When the two DNA sequences were compared, a close relationship ( $80 \%$ identity) between bases 1-840 in Fig. 5, which completely includes the $\operatorname{ram} A$ gene, and bases $1262-2105$ in the rom $A$-containing fragment was found. However, the Ent. cloacae homologue of the $\operatorname{ram} A$ gene is not the $\operatorname{rom} A$ gene identified in the original study of 

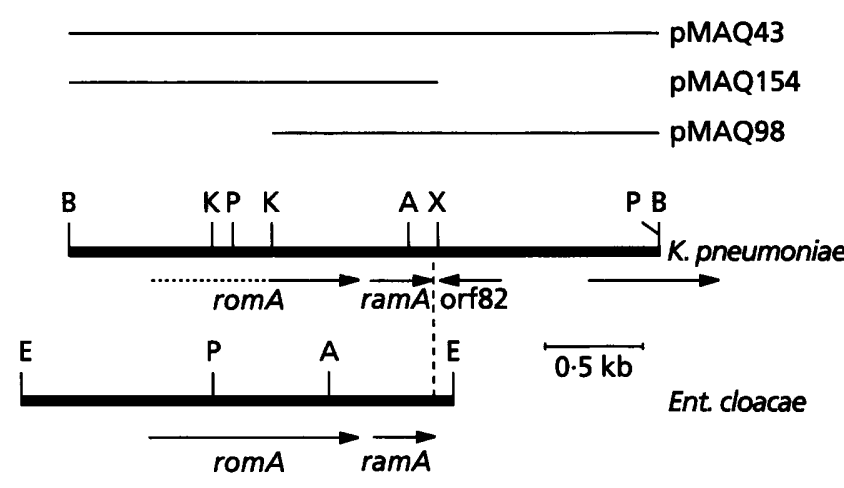

Fig. 4. Map of $3.0 \mathrm{~kb} \mathrm{BamHI}$ fragment of $K$. pneumoniae and location of the ramA gene. The thick black line indicates the $3.0 \mathrm{~kb} \mathrm{BamHI}$ fragment. Thin black lines above indicate the DNA sequences present in plasmids pMAQ43, pMAQ154 and pMAQ98. The positions of $\operatorname{ramA}$, romA and orf82 and a putative ATPase-dependent cation transporter gene are indicated by horizontal bars with the direction of transcription indicated by the arrows. Solid lines indicate sequenced regions. A map of the $2.2 \mathrm{~kb}$ EcoRl fragment of Ent. cloacae that includes the romA gene, derived from the data in Komatsu et al. (1990), shows the position of the $\operatorname{ram} A(E)$ gene identified in the present study. The vertical dashed line indicates the end of significant DNA similarity between the $K$. pneumoniae and Ent. cloacae DNA fragments. Restriction sites: A, Accl; B, BamHI; E, EcoRl; K, Kpnl; P, Pstl; X, Xhol.

Komatsu et al. (1990) but a gene located downstream of $\operatorname{rom} A$ (Fig. 4) and here designated $\operatorname{ram} A(\mathrm{E})$. The $\mathrm{C}$ terminal region of a homologue of the $\operatorname{rom} A$ is present upstream of the Klebsiella ram $A$ gene (see Figs 4 and 5) but due to differences between the two sequences that introduce frame-shifts, the predicted Klebsiella and Enterobacter RomA sequences differ from the position marked $(+)$ in Fig. 5. Immediately downstream of $\operatorname{ram} A$, the Klebsiella and Enterobacter sequences diverge and thus no further ORFs are common to both sequences. The fact that the complete rom $A$ gene is not present in pMAQ98 which confers an Mdr phenotype, indicates that the $K$. pneumoniae rom $A$ gene is not responsible for $\mathrm{Mdr}$ and it is therefore likely that the $\operatorname{ram} A(\mathrm{E})$ gene rather than $\operatorname{rom} A$ is responsible for the $\mathrm{Mdr}$ phenotype conferred by the cloned $2 \cdot 2 \mathrm{~kb}$ Enterobacter fragment.

\section{DISCUSSION}

K. pneumoniae mutants, isolated on the basis of resistance to chloramphenicol or nalidixic acid, were found to exhibit cross-resistance to a wide range of antibiotics including tetracycline, penicillins and cephalosporins, nalidixic acid, norfloxacin and puromycin. A reduced level of one of the major OMPs was also observed, and these Mdr mutants are clearly of the same class as those isolated in previous studies (Williams Smith, 1976; Gutmann et al., 1985). However, the spontaneous Mdr mutants of $K$. pneumoniae exhibit substantially higher antibiotic resistance than the levels of resistance in onestep spontaneous Mar mutants of E. coli (George \& Levy, 1983a). For this reason $\mathrm{Mdr}$ mutants of $K$. pneumoniae are important in the clinical context, and they are also important in the veterinary context since $\mathrm{Mdr}$ mutants have been isolated from chickens after treatment with either trimethoprim or chloramphenicol (Williams Smith, 1976). We have extended the characterization of these mutants by examining the energy-dependent transport of tetracycline and chloramphenicol in whole cells. Whereas energy-dependent accumulation of tetracycline occurred in wild-type cells, the Mdr1 mutant exhibited active efflux of tetracycline similar to that observed with E. coli Mar mutants (George \& Levy, 1983a). In the case of chloramphenicol, energy-dependent reduced uptake was observed in both wild-type and mutant cells, but the reduction in uptake was greater for the $\mathrm{Mdr}$ mutant. These effects are also similar to those observed recently in susceptible $E$. coli cells and in Mar mutants (McMurry et al., 1994). The transport of antibiotics into cells requires that they cross both the outer and the inner membrane and a role for the outer membrane in determining the level of uptake of, and thus resistance to, several antibiotics has been demonstrated (Nikaido, 1989). Though the reduction in the level of one of the major outer membrane porins (OmpF in E. coli) is the most obvious phenotype of both Mar and Klebsiella Mdr mutants, loss of OmpF alone cannot account for the $\mathrm{Mdr}$ phenotype, as Mar mutants can be isolated from $E$. coli mutants deficient in the production of OmpF (Cohen et al., 1989). Inner-membrane proteins also play a role in determining the levels of resistance to antibiotics, and active efflux of antibiotics is being increasingly recognized as a mechanism of resistance to antimicrobial agents (Levy, 1992). In E. coli, several intrinsic efflux systems which export tetracycline (McMurry et al., 1983), norfloxacin (Cohen et al., 1988a), ethidium bromide (Lambert \& Le Pecq, 1984) and chloramphenicol (McMurry et al., 1994; this study) have been recognized. It is possible that the interactions which determine the composition of the outer and the inner membranes are complex, and that changes in the uptake of antibiotics observed in Mdr mutants are caused by a series of changes in both the inner and the outer membrane composition. Our finding that the expression of resistance to chloramphenicol lags behind expression of resistance to other antibiotics when the $\operatorname{ram} A$ locus is introduced into susceptible $E$. coli cells suggests that resistance to chloramphenicol may require events different or secondary to those required for the expression of resistance to the other antibiotics.

Because of the similarities in the phenotypes of $\mathrm{Mdr}$ mutants of $K$. pneumoniae and Mar mutants of E. coli, it is tempting to speculate that these two classes of mutants are equivalent. Indeed, evidence that the mar locus is widely spread among the enteric bacteria has been reported (Cohen et al., 1993b). Hybridization with an E. coli $\operatorname{mar} R A B$ probe was detected in Southern blots of DNA from Klebsiella oxytoca and Ent. cloacae under high stringency conditions, and it was concluded that homologues of the mar operon exist in these organisms (Cohen et al., 1993b). However, in the present study, only weak hybridization was observed in digests of $K$. pneumoniae DNA using an equivalent probe (data not shown). A 
rOMA>

KpRI

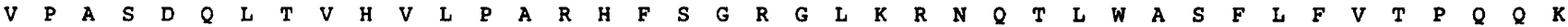

200

GATTTATTACAGCGGCGACAGCGGGTATGGGCCGCACTTTAAAGCGATAGGCGATGAGTTCGGTCCGGTCGATCTGGCGATCATGGAGAACGGGCAGTATGACCAGGACTGGAAATATAT

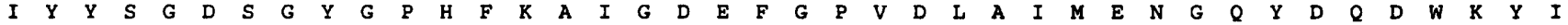

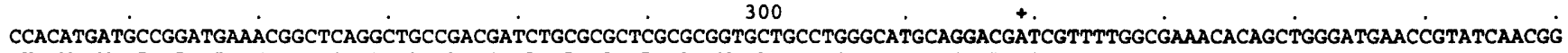

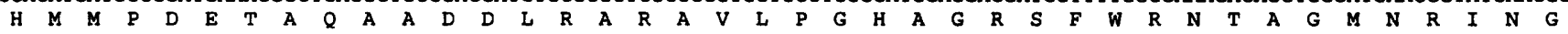

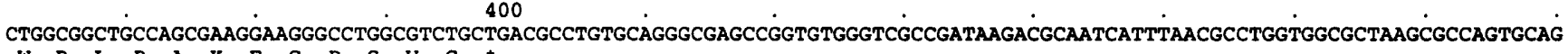

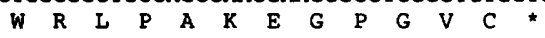
$\begin{array}{ccc}\text { RBS } & 500 & 600\end{array}$

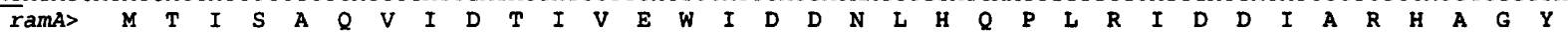

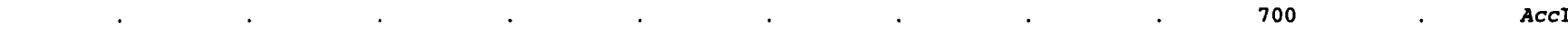
TCGAAATGGCATCTGCAACGGCTGTTTTTACAGTACAAAGGGGAGACCTGGGGGCTATATTCGCGAAAGGAGCTGCTGCTGGCCGCCCGCGATCTGCGCGACACCGATCAGCGGGTC

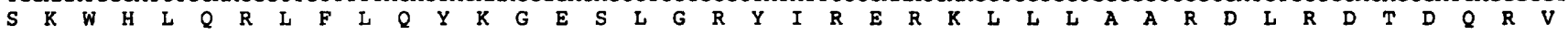

800

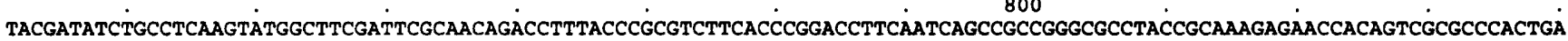

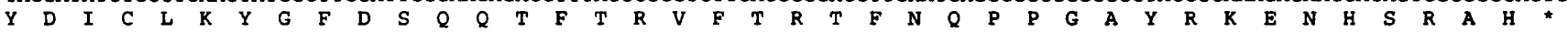
XhoI 900 GGCGCGCCTCTCCTGGTTTACCGCTCGAGGGAAACCAGCGACGCCACACCCAGCGCAGCACCAGATACTCAATGGCGCCCAGCGCTAAGAACCACAGACAAAACAGCACCGTATAGAGC $\begin{array}{lllllllllllllllllllllllllllllllllll} & * & R & E & L & S & F & W & R & R & W & V & W & R & \text { L } & \text { V } & \text { L } & \text { Y } & \text { E } & \text { I } & \text { A } & \text { G } & \text { L } & \text { A } & \text { L } & \text { F } & \text { W } & \text { L } & \text { C } & \text { F } & \text { L } & \text { V } & \text { T } & \mathbf{Y} & \text { L }\end{array}$

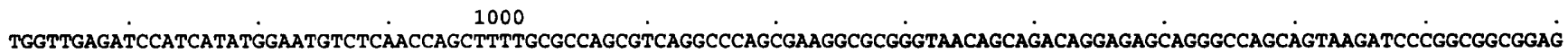

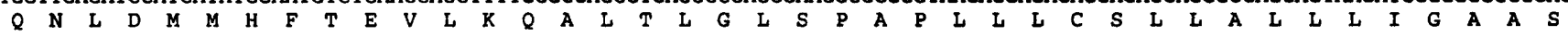
AGCAGCGTTTCCAGTGGATGTTTCATGTCATGTTAATCATCAGTTAAAAAACATATTGTCCGGTAAAATAATGCTTAACGCAATATGCTTTGTTTTTTTACTCGCTATAACACGACTATT

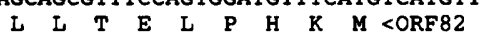

TTAAATATTATCGCCTGCCTTTCGCTCTCATGTTAATTAATCTGAAATAATTTGTAATTAAGTTAATTGCAGCGGGTGTAAATTAACGTCATTATTATGCCAGCGCTTTTACAAAACTGT

1400

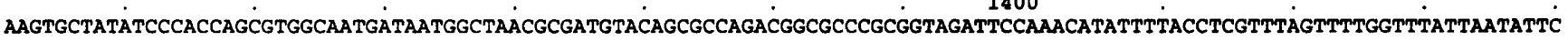

TGTAATAGTTGGTTGTGGAATTAACTTATCACAAAATTTTTATTTTGCGAAAATTTAGACTTGTATTGGTTCACATTTTTATGCGGCATTTTTGCCCTCTTTTACTTCATTGGCCAGG 1600

AATGATTTCAGGCTTTCCGACTCACGGAATTTATAAGGAAAATGTAAATTGACCAAGATGAATAACCCAAAGTTTACGACGCCCTCGGGCGACACCGCGCCACGGCAGGTCTGGCAGCAG $\begin{array}{lllllllllllllllllllllllll}M & N & N & P & K & F & T & T & P & S & G & D & T & A & P & R & Q & V & W & Q & Q\end{array}$

1700

ACCGTTGACGCAGTGCTGGCGCAGACTAAAAGCCAGGCCGCTGgGTTAAGTTCCGCAGACGCCGCCGAgCGCCTGAATACCTGTGGGCCGAATGCGCTGCCGGAAAAGAAAgGCAACCG

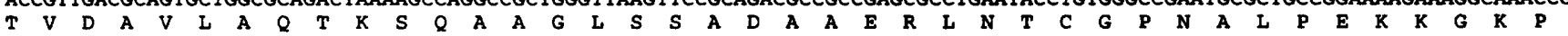
GGCTGGCTGCGCTTTCTCGCCCACTTTAACGACGTACTGATTTACGTGCTGCTGGCCGCCGCGGCGCTGACCGCCATCATGGGGCACTGGGTCGATACCCTTGTGATCCTCGGCGTGACG

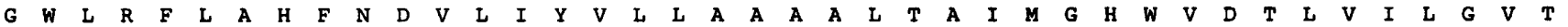

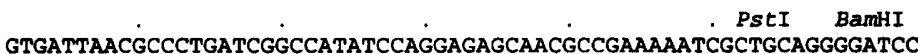

$\begin{array}{lllllllllllllllllllll}V & I & N & A & L & I & G & H & I & Q & E & S & N & A & E & K & S & L & Q & G & I\end{array}$

Fig. 5. Nucleotide sequence of the $K$. pneumoniae $\operatorname{ramA}$ gene and surrounding regions. The predicted amino acid sequences of RamA and a short ORF designated orf82 are shown. The C-terminal region of RomA and the $\mathrm{N}$-terminal region of an ORF which displays similarity to ATPase-dependent cation transporters are also shown. The predicted ribosome-binding site (RBS) for ramA and the -10 and -35 promoter regions for orf82 are underlined. The point of divergence of the Klebsiella RomA sequence from that of Enterobacter due to a frame-shift is indicated by + .

$1.24 \mathrm{~kb}$ probe containing the $E$. coli $\operatorname{marR} A B$ genes hybridized to the expected $16 \mathrm{~kb} \mathrm{BamHI}$ and $9 \mathrm{~kb} P s t \mathrm{I}$ fragment of E. coli (ÄG100) DNA (Hachler et al., 1991), and also gave weak hybridization signals with single bands in BamHI and Pst digests of ECL8 Mdr1 DNA, indicating that there may be mar-like sequences in $K$. pneumoniae as suggested in the study of Cohen et al. (1993b). However, when we compared the sequences of several pairs of genes, for which both $E$. coli and $K$. pneumoniae sequences are available, less than $70 \%$ DNA identity was found: thus, it might not be expected that a mar region homologue in $K$. pneumoniae would necessarily be detected using an $E$. coli probe, particularly under stringent conditions. It remains to be unequivocally established if the mar region is in fact present in the $K$. pneumoniae genome and, if so, whether it is also the 


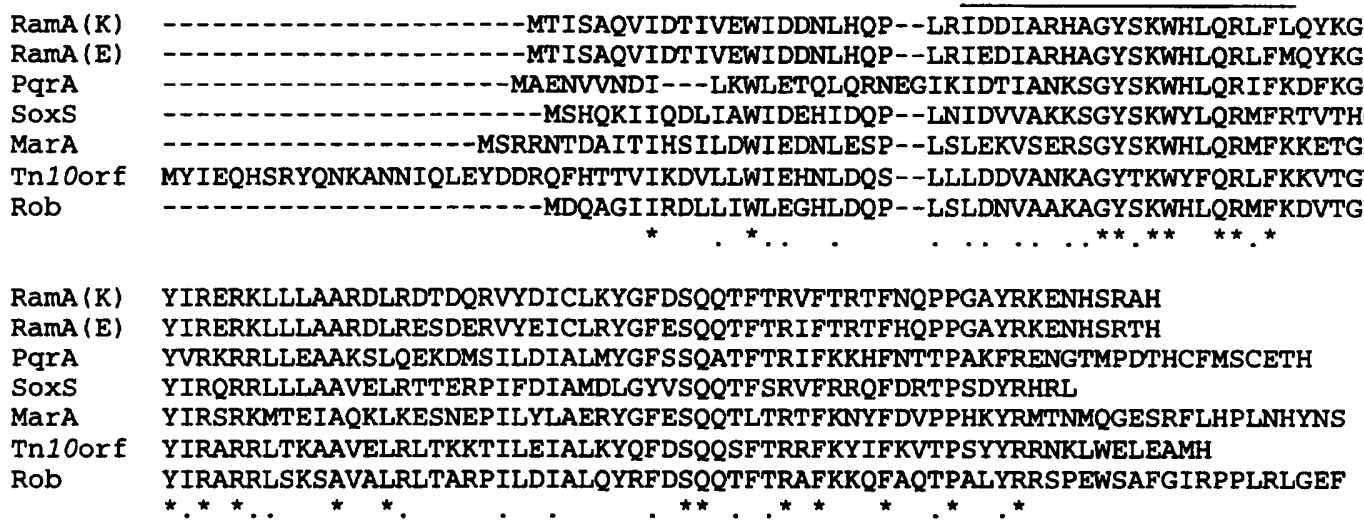

Fig. 6. Comparison of the derived amino acid sequences of the $K$. pneumoniae RamA protein (RamA(K)), Ent. cloacae RamA protein (RamA(E)), PqrA (GenBank accession no. D13561), SoxS (accession no. M60111), MarA (accession no. L06966), Tn100rf (accession no. J01830) and Rob (accession no. M97495). For Rob, only the first 120 amino acids are shown. Identical amino acids are indicated with an asterisk (*); conservative amino acid substitutions are indicated with a dot(.). Substitutions were designated conservative if all amino acids fall within one of the following exchange groups: T, S, A, G, P; R, K, H; F, W, Y; D, E, Q, N; I, L, M, V; and C (Dayhoff et al., 1978). The helix-turn-helix region (overlined) was predicted according to Dodd \& Egan (1987).

location of the mutations in the Mdr mutants studied here.

A DNA fragment from the $K$. pneumoniae Mdr1 mutant conferred on $E$. coli multiple-antibiotic resistance and other phenotypes (a substantial reduction in the level of OmpF, and changes in the energy-dependent uptake of tetracycline and chloramphenicol) essentially identical to those observed in the $K$. pneumoniae Mdr1 mutant. However, the region cloned in this study does not contain the putative Klebsiella equivalent of the $\operatorname{mar} \mathrm{R} A B$ region of $E$. coli, as the $3.0 \mathrm{~kb} \mathrm{BamHI}$ cloned fragment was not detected by hybridization of the $\operatorname{marR} A B$ probe to $K$. pneumoniae DNA or to pMAQ43 (data not shown). Furthermore, the sequence of the polypeptide predicted from the $\operatorname{ram} A$ gene was only about $40 \%$ identical to the MarA protein and the sequences of the corresponding genes are not significantly related. Though the effects of the cloned Klebsiella $\operatorname{ram} A$ gene are similar to those of the E. coli mar $A$ gene cloned in a multicopy vector (Gambino et al., 1993), the fact that the sequences of the RamA and MarA proteins are not closely related precludes the immediate conclusion that RamA can directly substitute for MarA and induce expression of the same set of genes. Intriguingly, it has recently been found that the cloned E. coli soxS gene also confers a Mar phenotype on E. coli (Miller et al., 1994), even though SoxS and MarA share limited sequence identity (39\%). In this case other evidence suggests that both MarA and SoxS can regulate the expression of a common set of genes. Certain of the soxRS-regulated oxidative stress genes of E. coli are also activated by mutations $(\operatorname{sox} Q)$ in the mar region (Greenberg et al., 1991), and soxQ mutations have recently been shown to be located in the marR gene (Ariza et al., 1994). However, the RamA protein is not closely related to SoxS ( $44 \%$ identity) and is thus also unlikely to be the $K$. pneumoniae SoxS equivalent. Nonetheless, it is possible that this set of transcriptional activators (MarA, SoxS and RamA) can each recognize the same or closely related regulatory signals in the DNA and can activate some or all of a single set of co-regulated genes. Expression of each of these transcriptional activators might be affected by different environmental signals. An alternative possibility is that the presence of the E. coli soxS gene or the $K$. pneumoniae $\operatorname{ram} A$ gene in $E$. coli indirectly induces the expression of MarA-regulated genes by causing the mar operon to be expressed. Indeed, elevated levels of the mar $\mathrm{R} A B$ transcript were observed in E. coli containing a plasmid carrying the soxS gene (Miller et al., 1994). Thus, the possibility that the mar operon plays a role in the expression of the many pleiotropic phenotypes caused by the introduction of $\operatorname{ram} A$ into $E$. coli warrants further investigation.

In this study the $2 \cdot 2 \mathrm{~kb}$ EcoRI Ent. cloacae fragment (Komatsu et al., 1990, 1991), which confers on E. coli a multiple-antibiotic resistance phenotype similar to that conferred by $\operatorname{ram} A$ and also causes a reduction in the level of OmpF, was found to contain a gene that is closely related to the $K$. pneumoniae $\operatorname{ram} A$ gene. Previously the $\operatorname{rom} A$ gene, which encodes a 368 amino acid putative OMP (Komatsu et al., 1990), was identified as being responsible for the $\mathrm{Mdr}$ phenotype. However, this conclusion is unlikely to be correct. Though the $\operatorname{rom} A$ gene is also present upstream of $\operatorname{ram} A$ in $K$. pneumoniae, the complete $\operatorname{rom} A$ gene is not present in $\mathrm{PMAQ} 98$ which confers an $\mathrm{Mdr}$ phenotype. The Enterobacter rom $A-\operatorname{ram} A$ fragment was cloned from a strain which exhibited resistance only to $\beta$-lactam antibiotics, and it also confers an $\mathrm{Mdr}$ phenotype when introduced into this strain (Komatsu et al., 1990). The cloned fragment is thus likely to contain the wild-type allele of the active gene, and the $\mathrm{Mdr}$ phenotype conferred by the cloned gene may result from over-expression of the gene due to its presence on a multicopy plasmid as is believed to be the case for the cloned $\operatorname{mar} A$ gene (Gambino et al., 1993). Though the $K$. pneumoniae $\operatorname{ram} A$ gene cloned in the present study was derived from an $\mathrm{Mdr}$ mutant, the mutation responsible 
for the Mdr phenotype does not appear to be within the $\operatorname{ram} A$ gene, as $\operatorname{ram} A$ cloned from the antibiotic-sensitive parental strain has the same sequence and confers an $\mathrm{Mdr}$ phenotype in $E$. coli. It is also likely that the recently reported $\operatorname{pqr} A$ gene cloned from Proteus vulgaris does not include the original Mdr mutation (Ishida et al., 1995). In $E$. coli, the mutations found in Mar strains are located within the mar $O$ or $m a r R$ regions, and MarR is believed to interact with $\operatorname{mar} O$ to regulate the expression of the $\operatorname{mar} A$ gene (Cohen et al., 1993a). The cloned fragment that confers a Mar phenotype contains only the $\operatorname{mar} A$ gene, presumably resulting in constitutive expression of $\operatorname{mar} A$ (Gambino et al., 1993). Likewise, expression of the soxS gene is likely to be regulated by the adjacent divergently transcribed sox $\mathrm{R}$ gene, and a Mar mutant with a mutation that maps in this region is presumed to be a mutation in sox $\mathrm{R}$ that leads to constitutive expression of sox $S$ (Miller et al., 1994). If this analogy holds in K. pneumoniae, then it might be predicted that expression of RamA would also be regulated and that the mutations responsible for $\mathrm{Mdr}$ could disrupt this regulatory system. The effects of the cloned $\operatorname{ram} A$ gene may then be due to the constitutive expression of $\operatorname{ram} A$ from the vector promoter.

\section{ACKNOWLEDGEMENTS}

The authors wish to acknowledge Dr R. G. Forage who made the initial observation of the Mdr phenotype in the laboratory of E. C. C. Lin, and brought this phenomenon to our attention. We also thank Georgia Grammaticopoulos, Amanda J. Phelps and Samantha Ginn for technical assistance. This work was supported in part by a University of Technology Sydney Research Grant to A.M.G. and a Macquarie University Research Grant to H.W.S.

\section{REFERENCES}

Abdel-Sayed, S. (1987). Transport of chloramphenicol into sensitive strains of Escherichia coli and Pseudomonas aeruginosa. $J$ Antimicrob Chemother 19, 7-20.

Amabile-Cuevas, C. F. \& Demple, B. (1991). Molecular characterization of the soxRS genes of Escherichia coli: two genes control a superoxide stress regulon. Nucleic Acids Res 19, 4479-4484.

Ariza, R. R., Cohen, S. P., Bachhawat, N., Levy, S. B. \& Demple, B. (1994). Repressor mutations in the $\operatorname{mar} R A B$ operon that activate oxidative stress genes and multiple antibiotic resistance in Escherichia coli. J Bacteriol 176, 143-148.

Berger, E. A. \& Heppel, L. A. (1974). Different mechanisms of energy coupling for the shock-sensitive and shock-resistant amino acid permeases of Escherichia coli. J Biol Chem 249, 7747-7755.

Birnboim, H. C. \& Doly, J. (1979). A rapid alkaline extraction procedure for screening recombinant plasmid DNA. Nucleic Acids Res 7, 1513-1523.

Cohen, S. P., Hooper, D. C., Wolfson, J. S., Souza, K. S., McMurry, L. M. \& Levy, S. B. (1988a). Endogenous active efflux of norfloxacin in susceptible Escherichia coli. Antimicrob Agents Chemother 32, 1187-1191.

Cohen, S. P., McMurry, L. M. \& Levy, S. B. (1988b). mar $A$ locus causes decreased expression of OmpF porin in multiple-antibioticresistant (Mar) mutants of Escherichia coli. J Bacteriol 170, 5416-5422.

Cohen, S. P., McMurry, L. M., Hooper, D. C., Wolfson, J. S. \& Levy, S. B. (1989). Cross-resistance to fluoroquinolones in multipleantibiotic-resistant (Mar) Escherichia coli selected by tetracycline or chloramphenicol: decreased drug accumulation associated with membrane changes in addition to OmpF reduction. Antimicrob Agents Chemother 33, 1318-1325.

Cohen, S. P., Hachler, H. \& Levy, S. B. (1993a). Genetic and functional analysis of the multiple antibiotic resistance (mar) locus in Escherichia coli. J Bacteriol 175, 1484-1492.

Cohen, S. P., Yan, W. \& Levy, S. B. (1993b). A multidrug resistance regulatory chromosomal locus is widespread among enteric bacteria. J Infect Dis 168, 484-488.

Dang, P., Gutmann, L., Quentin, C., Williamson, R. \& Collatz, E. (1988). Some properties of Serratia marcescens, Salmonella paratyphi $A$, and Enterobacter cloacae with non-enzyme-dependent multiple resistance to $\beta$-lactam antibiotics, aminoglycosides, and quinolones. Rev Infect Dis 10, 899-904.

Dayhoff, M. O., Schwartz, R. M. \& Orcott, B. L. (1978). In Atlas Of Protein Sequence and Structure, vol. 5, suppl. 3, pp. 345-352. Edited by M. O. Dayhoff. Washington, DC: National Biomedical Research Foundation.

Devereux, J., Haeberli, P. \& Smithies, O. (1984). A comprehensive set of sequence analysis programs for the VAX. Nucleic Acids Res 12, 387-395.

Dodd, I. B. \& Egan, J. B. (1987). Systematic method for the detection of potential $\lambda$ Cro-like DNA binding regions in proteins. J Mol Biol 194, 557-564.

Forage, R. G. \& Lin, E. C. C. (1982). DHA system mediating aerobic and anaerobic dissimilation of glycerol in Klebsiella pneumoniae NCIB 418. J Bacteriol 151, 591-599.

Gambino, L., Gracheck, S. J. \& Miller, P. F. (1993). Overexpression of the MarA positive regulator is sufficient to confer multiple antibiotic resistance in Escherichia coli. J Bacteriol 175, 2888-2894.

George, A. M. \& Levy, S. B. (1983a). Amplifiable resistance to tetracycline, chloramphenicol and other antibiotics in Escherichia coli : involvement of a non-plasmid determined efflux of tetracycline. $J$ Bacteriol 155, 531-540.

George, A. M. \& Levy, S. B. (1983b). Gene in the major cotransduction gap of the Escherichia coli K-12 linkage map required for the expression of chromosomal resistance to tetracycline and other antibiotics. J Bacteriol 155, 541-548.

Greenberg, J. T., Chou, J. H., Monach, P. A. \& Demple, B. (1991). Activation of oxidative stress genes by mutations at the soxQ/ cf $x B /$ mar $A$ locus of Escherichia coli. J Bacteriol 173, 4433-4439.

Gutmann, L., Williamson, R., Moreau, R., Kitzis, M.-D., Collatz, E., Acar, J. F. \& Goldstein, F. W. (1985). Cross-resistance to nalidixic acid, trimethoprim, and chloramphenicol associated with alterations in the outer membrane proteins of Klebsiella, Enterobacter, and Serratia. J Infect Dis 151, 501-507.

Hachler, H., Cohen, S. P. \& Levy, S. B. (1991). $\operatorname{mar} A$, a regulated locus which controls expression of chromosomal multiple antibiotic resistance in Escherichia coli. J Bacteriol 173, 5532-5538.

Hirai, K., Aoyama, H., Suzue, S., Irikura, T., lyobe, S. \& Mitsuhashi, S. (1986). Isolation and characterization of norfloxacin-resistant mutants of Escherichia coli K-12. Antimicrob Agents Chemother 30, 248-253.

Hooper, D. C., Wolfson, J. S., Souza, K. S., Ng, E. Y., McHugh, G. L. \& Swartz, M. N. (1989). Mechanisms of quinolone resistance in Escherichia coli: characterization of $n f x B$ and $c f x B$, two mutant resistance loci decreasing norfloxacin accumulation. Antimicrob Agents Chemother 33, 283-290.

Hooper, D. C., Wolfson, J. S., Bozza, M. A. \& Ng, E. Y. (1992). Genetics and regulation of outer membrane protein expression by quinolone resistance loci $n f \times B, n f \times C$, and $c f \times B$. Antimicrob Agents Chemother 36, 1151-1154. 
Higgins, D. G., Bleasby, A. J. \& Fuchs, R. (1992). ClustalV: improved software for multiple sequence alignment. Comput Appl Biosci 8, 189-191.

Innis, M. A. \& Gelfand, D. H. (1990). Optimization of RCR. In PCR Protocols: a Guide to Methods and Applications. Edited by M. A. Innis, D. H. Gelfand, J. J. Asninsky \& T. J. White. San Diego, CA: Academic Press.

Inokuchi, K., Itoh, M. \& Mizushima, S. (1985). Domains involved in osmoregulation of the $o m p F$ gene in Escherichia coli. J Bacteriol $164,585-590$.

Ishida, H., Fuziwara, H., Kaibori, Y., Horiuchi, T., Sato, K. \& Osada, Y. (1995). Cloning of the multidrug resistance gene $\operatorname{pgr} A$ from Proteus vulgaris. Antimicrob Agents Chemother 39, 453-457.

Komatsu, T., Ohta, M., Kido, N., Arakawa, Y., Ito, H., Mizuno, T. \& Kato, N. (1990). Molecular characterization of an Enterobacter cloacae gene (rom $A$ ) which pleiotropically inhibits the expression of Eschericbia coli outer membrane proteins. J Bacteriol 172, 4082-4089.

Komatsu, T., Ohta, M., Kido, N., Arakawa, Y., Ito, H. \& Kato, N. (1991). Increased resistance to multiple drugs by introduction of the Enterobacter cloacae rom $A$ gene into OmpF porin-deficient mutants of Escherichia coli K-12. Antimicrob Agents Chemother 35, 2155-2158

Laemmli, U. K. (1970). Cleavage of structural proteins during the assembly of the head of bacteriophage T4. Nature 227, 680-685.

Lambert, B. \& Le Pecq, J.-B. (1984). Effect of mutation, electric membrane potential, and metabolic inhibitors on the accessibility of nucleic acids to ethidium bromide in Escherichia coli cells. Biocbemistry 23, 166-176.

Lea, D. E. \& Coulsen, C. A. (1949). The distribution of the number of mutants in bacterial populations. J Genet 49, 264-285.

Levy, S. B. (1992). Active efflux mechanisms for antimicrobial resistance. Antimicrob Agents Chemother 36, 695-703.

Maniatis, T., Fritsch, E. F. \& Sambrook, J. (1982). Molecular Cloning: a Laboratory Manual. Cold Spring Harbor, NY: Cold Spring Harbor Laboratory.

Markwell, M. A. K., Haas, S. M., Bieber, L. L. \& Tolbert, N. E. (1978). A modification of the Lowry procedure to simplify protein determination in membrane and lipoprotein samples. Anal Biochem 87, 206-210

McMurry, L. M., Petrucci, R. E., Jr \& Levy, S. B. (1980). Active efflux of tetracycline encoded by four genetically different tetracycline resistance determinants in Escherichia coli. Proc Natl Acad Sci US A 77, 3974-3977.

McMurry, L. M., Aronson, D. A. \& Levy, S. B. (1983). Susceptible Eschericbia coli cells can actively excrete tetracyclines. Antimicrob Agents Chemother 24, 544-551.

McMurry, L. M., Park, B. H., Burdett, V. \& Levy, S. B. (1987). Energy-dependent efflux mediated by class $\mathrm{L}$ (TetL) tetracycline resistance determinant from Streptococci. Antimicrob Agents Chemother 31, 1648-1650.

McMurry, L. M., George, A. M. \& Levy, S. B. (1994). Active efflux of chloramphenicol in susceptible Escherichia coli strains and in multiple-antibiotic-resistant (Mar) mutants. Antimicrob Agents Chemother 38, 542-546.

Miller, P. F., Gambino, L. F., Sulavik, M. C. \& Gracheck, S. J. (1994). Genetic relationship between soxRS and mar loci in promoting multiple antibiotic resistance in Escherichia coli. Antimicrob Agents Chemother 38, 1773-1779.

Nikaido, H. (1989). Outer membrane barrier as a mechanism of antimicrobial resistance. Antimicrob Agents Chemother 33, 1831-1836.

Park, B. H. \& Levy, S. B. (1988). The cryptic tetracycline resistance determinant on Tn 4400 mediates tetracycline degradation as well as tetracycline efflux. Antimicrob Agents Chemother 32, 1797-1800.

Pfeiffer, L. (1889). Ueber einen neuen Kapsel-Bacillus. Z Hyg 6, 145-150.

Pugsley, A. P. \& Schnaitman, C. A. (1978). Identification of three genes controlling production of new outer membrane pore proteins in Escherichia coli K-12. J Bacteriol 135, 1118-1129.

Ramos, J. L., Rojo, F., Zhou, L. \& Timmis, K. N. (1990). A family of positive regulators related to the Pseudomonas putida TOL plasmid $\mathrm{XylS}$ and the Escherichia coli AraC activators. Nucleic Acids Res 18, 2149-2152.

Rosen, B. P. \& Kashket, E. R. (1978). Energetics of active transport. In Bacterial Transport, pp. 559-620. Edited by B. P. Rosen. New York: Marcel Dekker.

Sanders, C. C., Sanders, W. E., Jr, Goering, R. V. \& Werner, V. (1984). Selection of multiple antibiotic resistance by quinolones, $\beta$-lactams, and aminoglycosides with special reference to crossresistance between unrelated drug classes. Antimicrob Agents Chemother 26, 797-801.

Silhavy, T. J., Berman, M. L. \& Enquist, L. W. (1984). Experiments with Gene Fusions. Cold Spring Harbor, NY: Cold Spring Harbor Laboratory.

Szybalski, W. \& Bryson, V. (1952). Genetic studies on microbial cross resistance to toxic agents. I. Cross resistance of Escherichia coli to fifteen antibiotics. $J$ Bacteriol 64, 489-499.

Then, R. L. \& Angehrn, P. (1986). Multiply resistant mutants of Enterobacter cloacae selected by $\beta$-lactam antibiotics. Antimicrob Agents Chemother 30, 684-688.

Traub, W. H. \& Kleber, I. (1977). Selected and spontaneous variants of Serratia marcescens with combined resistance against chloramphenicol, nalidixic acid, and trimethoprim. Chemotherapy 23, 436-451.

Williams Smith, H. (1976). Mutants of Klebsiella pneumoniae resistant to several antibiotics. Nature 259, 307-308.

Wu, J. \& Weiss, B. (1991). Two divergently transcribed genes, sox $R$ and soxS, control a superoxide response regulon of Escberichia coli. $J$ Bacteriol 173, 2864-2871.

Yanisch-Perron, C., Vieira, J. \& Messing, J. (1985). Improved M13 phage cloning vectors and host strains : nucleotide sequences of the M13mp18 and PUC19 vectors. Gene 33, 103-119.

Received 16 January 1995; accepted 28 March 1995. 